\title{
Law as an Instrument of Fighting Against Chemical, Biological, Radiological and Nuclear (CBRN) Terrorism
}

\author{
Leopold SKORUŠA ${ }^{1}$
}

\begin{abstract}
This contribution deals with the legal impacts on the protection of population against a specific form of terrorism. As a reference element for exploring the sub-jected, a regulating mechanism of legal character was selected by the author.

As the assessment of the regulation of all CBRN components are outside of the framework of this article, the author limited his survey to the area of combat chemical agents and industrially dangerous chemicals provided. The survey model applied can be utilised by other means as well.
\end{abstract}

Keywords: regulation, law, regulating means, chemical terrorism, CBRN, population protection

\section{Features of the Problem}

All too often we are reminded that terrorism continues to inflict pain and suffering on people all over the world. The existence of the threat of terrorism and its significance highlights the rightful interest of the society in paying due attention to the protection of population. It is the aim of that process to correctly diagnose a potential terrorist attack (or the handling of its effects) or to specify it as a serious threat, and to make an ultimate rational decision con- cerning its solution.

Terrorism takes on many forms and utilises various means to enforce its aims. The terror- ism of our day may be occasionally called superterrorism, meaning that it is capable of using chemical, biological, and radiological and nuclear weapons (CBRN terrorism). Even though the production and use of those weapons are strictly regulated by a number of international treaties, it is not entirely possible to prevent abuse. This is namely the case of chemical weap- ons which are surprisingly easy to obtain and yet highly effective when used.

The potential use of CBRN means, for terrorist purposes, it is undoubtedly to be considered one of the most dangerous forms of terrorism. Aside from chemical weapons created for the purpose of armed conflict, there are terrorist methods and means possessing the character de- scribed that do not utilise weapons or weapon systems; they exploit industrially produced toxic materials which can be disseminated in purposeful attacks aimed at peaceful infrastructure.

In its aim to fulfil its base functions, including the securing of the safety [1: 6] of the population, society is obliged to be able to resist the perils that can occur unexpectedly and threaten lives, well-being and property of citizens, as well as their living environment. The most suitable instrument for ensuring the optimum efficiency of the security system is its regulation.

1 Mgr.Ing.Ph.D.,University of Defence, Faculty of Military Leadership, Kounicova 65, 66210 Brno, e-mail: leopold.skorusa@unob.cz. 
A particular position in the regulation systems is occupied by normative legal systems, from which the law creates rules of behaviour (legal regulations) which are also of significant influence on the quality of social relationships that ensue in the course of the protection of the population from CBRN terrorism being secured.

Nowadays, authors from neighbouring countries have writen scientific papers concerning new challenges of CBRN defence, from technical [2] or administrative aspects. This paper focuses on legal issues.

\section{Protective Means - Regulations}

Due to its overall intricacy, it is nowadays quite necessary to view the safety and protection of people as a complex system. If we are to examine the mechanisms ensuring the functioning of a particular part of the security system of the Czech Republic, it is appropriate to examine it from the vantage point of the elements securing its optimum functions. The most suitable instrument for retaining the optimum efficiency of the security system is its regulation.

Regardless of the era, it has always held true that human society cannot function with- out utilising a certain number of regulatory mechanisms. [3: 161] Their aim is to ensure social interaction, solve conflicts ensuing from differing needs and interests of individuals or groups, and supply society with an order necessary for its existence. It is the only way to ensure social reproduction and to prevent entropy, towards which social life has an intrinsic tendency. [4: 29]

In general, regulation (be it executed by human factor or an automatic device - a regula- tor) is a directional or guiding conduct. In the context of society, regulation is the influence or control imposed on human or social behaviour by means of rules, precautions and restric- tions. In terms of physics, regulation is direction supplied with feedback. We are speaking of maintaining a certain value in a constant degree or one that changes according to a certain rule. Regulation is then applied in order to dispose of the discrepancies detected. As opposed to regulation, control is direction lacking feedback. [5: 6]

Regulations, at the same time, both condition and warrant order in a society. Without them, social interaction would be scarcely possible or at least much more difficult to exercise.

By establishing fixed rules of social cooperation, these regulations outrule case-by-case negotiations, prevent numerous conflicts and supply human conduct with steady forms.

They are therefore of assistance to people in the matter of deciding on a particular vari- ant of behaviour (the problem of free choice) and accommodate their need for assurance in social relationships. Regulations help maintain order in society by eliminating conflicts and deviations. [6: 161]

The functioning of public administration towards ensuring safety (protection) of people is supported by regulations (regulating mechanisms) in the form of various kinds of measures and precautions. In this context we can identify regulations that are in their character:

- organizational and technical,

- economical,

- legal,

- other. 


\section{Legal Regulations}

As has been mentioned, a human society is a complex mechanism that for its operation requires certain forms of regulation. If we operate on the anthropological premise that the human species merely exists within groups and that a human being is free and possessed of the ability of reproducing the world by means of thought (in terms or language) and choosing between alternatives of behaviour, then it appears vital to bring this freedom into accord with the freedom of others. ${ }^{2}$ [7: 66-67]

One of the most efficient means of regulation of the behaviour of both individuals and groups is undoubtedly normative regulation using restrictions, directions and permissions; or, certain norms of conduct. Dynamic and purposeful regulative systems of this kind are referred to as normative systems. In regards to the character of the norms of conduct two kinds of systems are distinguishable: non-legal normative systems ${ }^{3}$ and legal normative systems. Law occupies a particular position among these systems, since it presents itself as a set of rules of conduct of a distinct form created by the state and enforceable by the state. These rules of conduct (legal regulations) administer various categories of social relationships, among others those concerned with ensuring safety and protection of population of a particular country or an alliance of countries. [8: 162-168] Regulations of this kind consist in legally ensuring (for the population) the use of interests protected by law - for example, property is not considered the most important of these interests, since there are other, higher aspects of general well-being such as personal protection, honour, good, individual freedom and indi- vidual (or group) safety.

The process of regulation is usually defined by relevant formal aspects of certain pieces of information, inferred from the legitimacy and activities of the authority conducting the regulation.

In the field of legal regulations, state is traditionally the (organizational) authority cre- ating law. It is the characteristic feature of the way authority operates that the quality of the subject is projected into the information created by the form of a specific quality of said infor- mation, that is by form of its normativity (normative value), or the character of the regulation of the particular social relationship according to the idea of the authority which creates the regulations.

Legal regulations - legal norms can be in this context considered rules representing cer- tain alternatives of conduct, that aim to reach the satisfaction of the needs of a person both as an individual and as a member of a group. Nevertheless, man, being a thinking individual, is capable of volitional conduct. This marks the contrast between the individuality of a human being, their interests and aims, and the necessity of being a part of a group which is essential to the survival of an individual. [9: 104]

The relationship between freedom of an individual (and the ability to act independent- ly based on one's own will) and the possibility of reproduction being available only when living within a group is formulated by Kant, who stated, "any single thing in the natural

2 "Law is therefore a summary of the conditions under which it may be united together with the arbitrariness of one another according to the general law of liberty, justice ... Universal law of justice is thus: Deal outwardly so that the free use of your whim could coexist with the freedom of every man according to general law." [7: 66-67]

3 Author's Note: for example, more or less binding religious rules, rules, etiquette, etc. 
world works based on rules and principles... “. [7: 48-49] This means of administration is referred to as power. Power is thus capable of defining human conduct - that being realized by formulating (defining) the way of conduct required and ensuring its being followed. By formulating the kind of conduct required by power, a norm is created, which acts as a binding rule of human conduct (a regulation). A norm of this sort then becomes a part of the system of social administration which carries certain defining aspects. These aspects include its regu- lativeness and generality. The regulativeness of a norm is that it represents a certain direction as to a distinct kind of conduct, which puts restraint on the choice of alternatives of conduct of an individual or a group. Since the normative (legal) mechanism of the regulation of pub- lic security is the main referential component of the thesis, it is vital to present here specific aspects of legal regulations, which are: the connection of law and the authority of state, the universality of law, and the specific form in which law is formulated:

- State, represented by the bodies of state administration and self-government, is the subject of the creation or recognition (see international norms, European norms), as well as the subject of ensuring legal norms.

- The whole society (population in a broader sense) organized within the state that pos- sesses a system of public authority, is the addressee of legal norms. This means that the system of legal norms is an all- encompassing system within the society, and a legal norm is therefore a general regulation of state authority.

- A legal norm - regulation - has a form established or acknowledged by public authority and it is formulated in one of the forms of sources of law. ${ }^{4}$

\section{The Protection of the Population of the Czech Republic from Chemical Terrorism - Regulation}

The Czech Republic consistently reinforces security cooperation with countries that have successfully resisted the threat of terrorism, in an effort too participate in a joint approach. An important aspect of this understanding of international cooperation and exchange of informa- tion is participating in the activities proceeding within the European Union. Included are the aspects that the Czech Republic is currently trying to resolve or deems necessary to resolve in the immediate future. These are the topics projected in the contents of Národni akční plán boje proti terorismu (National Action Plan to Combat Terrorism) and Bezpečnostni strategie (Security Strategy). [10] Most attention is being paid to the regulations concerning the pro- tection of the critical infrastructure and the protection from an abuse of chemical, biological and nuclear substances by terrorists.

The current law of the Czech Republic includes the legal regulations necessary for as- sessing the ministries and other central bodies of administration, the administrative bodies of regions, municipalities and selected legal and physical persons with the tasks concerning the protection of population. Legal regulations concerning dangerous chemical substances in the Czech Republic issue mainly from the SEVESO directives accepted by the European Union.

It is namely the Act 59/2006 Coll., concerning prevention from grave disasters caused by selected dangerous chemical substances or chemical products, in the definition of subsequent

4 Author's Note: Sources of law are forms in which the objective law is provided. Usually it will be the rule of law by the state authorities with legislative powers (normative legal acts), legal customs, and the normative character of the contract (international agreements), precedents, and general legal principles. 
bylaws (the law concerning preventing grave disasters), Act 239/2000 Coll., concerning the integrated emergency system and the changes in certain laws, in the definition of subsequent bylaws, and Act 238/2000 Coll., concerning the Fire Rescue Service (FRS) of the Czech Re- public and the changes in certain laws, in the definition of subsequent bylaws. Order of Min- istry of Interior 380/2002 Coll. concerning the preparation and carrying out of the tasks for the protection of population defines and specifies the individual tasks. Thus are created the basic legal conditions for ensuring the protection of population, property and environment, connected among others to grave emergencies caused by selected chemical substances, fires and other technical and technological disasters of large extent, in addition to the treatment of emergency situations in supplying drinking water and provisions, in power supply and in gas and heat, and to grave terrorist attacks using CBRN means.

The system of prevention defined by the law concerning prevention of grave emergencies is a set of regulations that concern objects and facilities which contain dangerous chemical substance or product in the same or larger quantity than that set by the law.

The legal regulation administers:

- the duties of legal or physical persons who are in possession or who use the object or facility;

- the classification of said object or facility into respective groups based on the sort and quantity of the selected dangerous chemical substance or product;

- providing information to the public accompanying prevention of grave emergencies in said facility;

- the execution of state administration in the area of prevention of grave emergencies caused by selected dangerous chemical substances or products.

Integrated Rescue System (IRS) represents the base of coordination of tasks and ap- proaches of its respective units during the preparation for extraordinary events, during the rescue work and settling work, in terms of protection of population from CBRN terrorism. The dominant role in the system is represented by the regional fire rescue crews that consti- tute autonomous organizational units of the state. It is this subject of IRS that represents the most important element in the system of protection from potential CBRN terrorism. Research has been carried out that examines the influence of legal regulations over the efficiency of this element and also evaluates the capability of the subject as to fulfil the requirements laid out by the regulations.

The Fire Rescue Service of the Czech Republic and the fire rescue units fulfil tasks in the department of public security, technical interventions and fire protection during any extraor- dinary events and crisis situations including state of war. The FRS organizes IRS and partic- ipates in creating the emergency and crisis plans. It ensures and coordinates organizational and technical measures in the field of the protection of the public; particularly the warning, shelter, evacuation, survival in crisis and humanitarian aid.

By the Government Decree 165 (25 2 2008) The concept of the population protection in 2013 with a view to 2020 was approved. This policy, similarly to the policy of 2002, em- phasises the need of information and education in the field of the protection of population, reinforcement and material provisions to the units of IRS, the responsibility of ministries, central administrative bodies, municipalities and legal and physical persons for the protection of population. The evaluation of the preceding policy revealed that the system of protection is functioning. It is nevertheless possible to ask if the same can be ascertained as to the risks 
ensuing from CBRN terrorist attacks. In the following time, measures of both non-legislative and legislative character are accepted, which are included in the proposal tooptimize the current security system in the CR. One of the factors limiting further improvements in this department, especially those in the field of material provisions, is the financial budget.

The following demonstrative enumeration lists the most important legal regulations that influence chemical security:

- the Ministry of Foreign Affairs Decree 96/1975 Coll., the Convention on the Prohibi- tion of the Development, Production and Stockpiling of Bacteriological (Biological) and Toxin Weapons and on their Destruction;

- Act 19/1997 Coll., Some measures related to the prohibition of chemical weapons, as amended;

- Decree 208/2008 1975 Coll., implementing Act on some measures related to the prohibition of chemical weapons;

- Act 350/2011 Coll. of Chemical substances and mixtures and amending certain acts (chemical Act);

- Decree 103/2006 Coll. (21 03 2006) to establish principles for the definition of emer- gency planning zones and the extent and method of preparation of external emergency plan;

- Decree 250/2006 Coll. of L., (23 05 2006) laying down the scope and content of safety measures of physical protection of property or equipment assigned to group A or group B;

- Government Decree 254/2006 Coll. (24 05 2006) on the control of hazardous substances;

- Decree 255/2006 Coll. (22 05 2006) on the extent and manner of reporting on major accidents and the final report on the occurrence and effects of serious accidents,

- Decree 256/2006 Coll. (22 05 2006) on the details of the system for preventing major accidents;

- Mandatory Instruction 16/2002 Methodological Instruction the Department of Envi- ronmental Ministry of the Environment Risk assessment for the possibility of cumula- tive and synergistic effects of a serious accident;

- Mandatory Instruction 06/2006 Methodological Instruction of the Ministry of Envi- ronmental Department of the Environment for "Assessment of an object or device selected hazardous chemical substances or chemical products and to general legal obli- gations or individuals doing business" under Act 59/2006 Coll. on accident prevention;

- Methodological Instruction of the Environmental Risks Department of the of the Min- istry of Environment for the procedure for processing the document "Proposal for the inclusion of an object or device in group A or B" pursuant to Act 59/2006 Coll. on accident prevention;

- Methodological Instruction 9/2006 of the Environmental Risks Department of the of the Ministry of Environment for processing document "Principles, objectives and pol- icy to prevent accidents and "Description of the safety management system" pursuant to Act 59/2006 Coll. on accident prevention;

- Methodological Instruction 10/2006 of the Environmental Risks Department of the of the Ministry of Environment for the procedure for processing the document "Safety Report" by Act 59/2006 Coll. on the prevention of major accidents; 
- Mandatory Instruction 04/2007, Methodological Instruction of the Environmental Risks Department of the of the Ministry of Environment for "Provision of information on the occurrence and effects of serious accidents" under Act 59/2006 Coll. on the prevention of major accidents;

- Mandatory Instruction 05/2007, Methodological Instruction of the Environmental Risks Department of the Ministry of Environment for "Preparation of written docu- ments to determine the area of emergency planning and preparation for external emer- gency plan" pursuant to Act 59/2006 Coll. on accident prevention;

- Mandatory Instruction 23/2007, Methodological Instruction of the Environmental Risks Department of the Ministry of Environment for the procedure for processing a document entitled "Analysis and assessment of risk of serious accidents" under Act 59/2006 Coll., on accident prevention,

- Mandatory Instruction 24/2007, Methodological Instruction of the Environmental Risks Department of the of the Ministry of Environment on the scope and method of processing the document "Assessment of the influence of human factors to the object or equipment in connection with the relevant sources of risk" pursuant to Act $59 / 2006$

Coll., on Prevention of serious accidents.

There is also another area consisting of Czech legal regulations oriented towards count- er-terrorism activities. The basic premise of a successful fight against chemical terrorism is the ability of the respective government bodies to obtain, accumulate and forward informa- tion of the intentions and activities of terrorist structures to competent subjects in a timely manner. The authorities disposing with this competence are the intelligence departments and the law enforcement authorities. ${ }^{5}$ The efforts of the security forces play the role of prevention in this process. Its aim is to reveal any eventual terrorist activities (preparation for an attack) at their inception. Cooperation of the police forces and the intelligence is crucial in this pro- cess. Both forces complement each other and cooperate. Intelligence plays an important role in the phase of latent preparations for a terrorist attack, the police force on the other hand possesses the executive authority (e.g. for the commencement of criminal procedures). The surveillance and prosecution of a particular culprit (or a suspect) is also a matter of joint ef- fort. International collaboration in the pursuit of persons responsible for acts of terror plays a crucial role in this matter as well. [11: 706]

Following the government resolution of 2006 to coordinate the activities of intelligence agencies of the Czech Republic to analyse information vital for the security of the country, with special emphasis on the fight against terrorism, The Security Information Service was designated as a coordination point for accumulating and analysis of information concerning terrorism provided by Czech intelligence. The National Focal Point on Terrorism was established by the Police of the Czech Republic in 2009 and came into permanent operation in June of the same year. ${ }^{6}$ [12]

From the point of criminal law regulation, Czech law allows for prosecution of the entire scope of terrorist activities. ${ }^{7}$ To illustrate the situation further (and to substantiate the reality of the threat of chemical terrorism), allow me one remark from the resources of the police

5 Author's Note: law enforcement proceedings are regulative according to Czech police, prosecutors and courts

6 The Strategy for combating terrorism for years 2010 - 2012: Measures aimed at minimizing risk and impact of potential terrorist attack on the Republic and against the interests of the Republic abroad.

7 See in particular para 311 - terrorist attack - Act 40/2009 Coll. Criminal Code. 
SKORUŠA, Leopold: Law as an Instrument of Fighting Against Chemical, Biological, Radiological...

unit for combating organized crime: "there continues to arise a number of offers for illegal sale of these dangerous substances, that are in the area of the Czech Republic most often of-fered by Slovak, Ukrainian, Russian and Hungarian citizens. Czech citizens are often used as intermediaries in these transactions. The material offered is said to have originated in most cases from the countries of former Soviet Union."

\section{Conclusion}

Protection of the population - applying the optimum regulation system in regards to the safe- ty of citizens, including protection from CBRN terrorism, is a vital function of the state. It is an obligation of the state to create a security system that is necessary and to maintain this system in a working condition.

The ability of the state authority to enforce legal regulations represents one of its basic at- tributes. Attempts of the responsible authorities to "force" the public to identify with the sys- tem of regulation or to participate actively in the process, stands in contrast to the principles of a democratic state which allow only minimum (and only in the form of a law) interference with personal and personality rights.

A regulation mechanism functions best when functioning preventively, or at least flexibly in regard to reacting to external change. The process of changing legal regulations in the area of the protection of the population from CBRN terrorism is, according to experts, too lengthy and unable to react to new demands in a timely or adequate manner.

\section{References}

[1] VALÁŠEK, J., KOVÁŘÍK, F.: Crisis management in non-military crisis situations: Specialized publications for crisis management. Prague: Ministry of Interior - General Directorate of Fire Rescue Service, 2008.

[2] HALÁSZ L., PADÁNYI J., FÖLDI, L.: Improving the CBRN defence of combat vehicles as a response to the challenges of climate change. Economics and Management, 73 (2013), 31-38.

[3] VEČĚ̌A, M., URBANOVÁ, M.: Sociology of law. Pilsen: Aleš Čeněk Ltd, 2006. [4] KNAPP, V.:

Theory of Law. Prague: CH Beck, 1995.

[5] ŠVARC, I.: Automatic Control. Brno: Academic Publishing CERM, 2007.

[6] FUKUYAMA, F.: Great disruption: human nature and the reconstruction of social order. FALTÝSKOVÁ, A. (Transl.), Prague: Academia, 2006.

[7] KANT, I.: Die Metaphysik der Sitten. Stuttgart: Reclam, 1990.

[8] FILIP, J.: Selected topics to study constitutional law. $2^{\text {nd }}$ compl Ed. Brno: Masaryk University, 2001.

[9] HOLLÄNDER, P.: Philosophy of Law. Pilsen: Aleš Čeněk Ltd, 2006.

[10] CR Security Strategy 2011.www.mzv.cz/file/699914/Bezpecnostni_strategie_CR_2011.pdf (downloaded: 0704 2012)

[11] KLOUČKOVÁ, S., FENYK, J.: International judicial cooperation in criminal matters. $2^{\text {nd }}$ upd. and complement. Prague: Linde, 2005.

[12] The Strategie for combating terrorism for years 2010-2012. Prague: Ministry of Interior, 2010. 